\title{
Chemokines in tumor progression and metastasis
}

\author{
Purvaba J. Sarvaiya1, Donna Guo ${ }^{1}$, Ilya Ulasov ${ }^{1}$, Patrik Gabikian ${ }^{1}$ and Maciej S. \\ Lesniak ${ }^{1}$ \\ ${ }^{1}$ The Brain Tumor Center, The University of Chicago, Chicago, Illinois, USA \\ Correspondence to: Maciej S. Lesniak, email: mlesniak@surgery.bsd.uchicago.edu \\ Keywords: Chemokines, chemokine receptors, cancer, metastasis
}

Received: September 19,2013 Accepted: November 8, 2013

Published: November 9, 2013

This is an open-access article distributed under the terms of the Creative Commons Attribution License, which permits unrestricted use, distribution, and reproduction in any medium, provided the original author and source are credited.

\section{ABSTRACT:}

Chemokines play a vital role in tumor progression and metastasis. Chemokines are involved in the growth of many cancers including breast cancer, ovarian cancer, pancreatic cancer, melanoma, lung cancer, gastric cancer, acute lymphoblastic leukemia, colon cancer, non-small lung cancer and non-hodgkin's lymphoma among many others. The expression of chemokines and their receptors is altered in many malignancies and leads to aberrant chemokine receptor signaling. This review focuses on the role of chemokines in key processes that facilitate tumor progression including proliferation, senescence, angiogenesis, epithelial mesenchymal transition, immune evasion and metastasis.

\section{INTRODUCTION}

Chemokines are a group of small molecular weight proteins that bind to the $\mathrm{G}$ protein coupled chemokine receptors [1]. Chemokines play an important role in cell migration, development, immune surveillance, inflammation as well as in many pathological conditions [1]. Chemokines play a key role in regulating immune response and inflammation by their involvement in the regulation of leukocyte trafficking and positioning. The binding of the chemokines to the receptors leads to a conformational change, which activates signaling pathways and promotes migration. Chemokines and their receptors are divided into four families based on the pattern of cysteine residues: $\mathrm{CXC}, \mathrm{CC}, \mathrm{CX} 3 \mathrm{C}$ and $\mathrm{C}$, where $\mathrm{C}$ represents the cysteine and $\mathrm{X}$ represents noncysteine amino acids [2,3]. Approximately 20 chemokine receptors and 50 chemokines have been identified in humans, which are listed in Table I. Chemokines can also be divided into two groups based on their function: inflammatory chemokines and homeostatic chemokines. As the names suggest, inflammatory chemokines are induced by inflammation while homeostatic chemokines are constitutively expressed and are involved in homeostatic immune regulation.

Chemokine receptors are seven transmembrane spanning proteins coupled to G-protein-coupledreceptors (GPCRs). These receptors are named based on the chemokine ligands to which they bind $[2,3]$.
For example, CXC receptors (CXCR1, 2, 3, 4 and 5) bind CXC chemokines, $\mathrm{CC}$ receptors (CCR1, 2, 3, 4, 5, $6,7,8,9)$ bind $\mathrm{CC}$ chemokines; $\mathrm{CX} 3 \mathrm{C}$ receptor binds $\mathrm{CX} 3 \mathrm{C}$ chemokine and lastly, the $\mathrm{XC}$ receptor binds the $\mathrm{C}$ chemokine. In spite of the fact that chemokine receptors bind to their specific chemokine sub-groups, there is significant ligand promiscuity. Some chemokines can bind to and signal three chemokine receptors. Also, responses to some chemokine receptors could be elicited by as many as 10 ligands [4]. Furthermore, it is important to consider that there are differences in the mouse and human chemokine families. For example, CXCL8, CCL18, CCL23 are present in humans but absent in mice $[2,5]$. Hence, all of the observations in the mouse models cannot be generalized in humans. Furthermore, many posttranslational modifications affect the chemokine receptor signaling, receptor specificity as well as chemotactic property of chemokines and thus affect their biological functions. Some of the post-translational modifications in chemokines include glycosylation, citrullination, and proteolytic processing at the $\mathrm{N}$ and $\mathrm{C}$ terminus [6-9].

Chemokines play an important role in the progression of cancers. They are involved in tumor growth, senescence, angiogenesis, epithelial mesenchymal transition, metastasis and immune evasion. The expression of chemokines and their receptors is altered in many malignancies and subsequently leads to aberrant chemokine receptor signaling. This alteration occurs due to inactivation of the tumor suppressor genes or constitutive 
Table I: List of the chemokine receptors and chemokine ligands that bind to the receptors

\begin{tabular}{|l|l|}
\hline $\begin{array}{l}\text { Chemokine } \\
\text { Receptor }\end{array}$ & Chemokine Ligands \\
\hline CXCR1 & CXCL6, CXCL8 \\
\hline CXCR2 & $\begin{array}{l}\text { CXCL1, CXCL2, CXCL3, CXCL5, } \\
\text { CXCL7, CXCL8, CXCL6 }\end{array}$ \\
\hline CXCR3 & CXCL4, CXCL9, CXCL10, CXCL11, \\
\hline CXCR4 & CXCL12 \\
\hline CXCR5 & CXCL13 \\
\hline CXCR6 & CXCL16 \\
\hline CXCR7 & CXCL12, CXCL11 \\
\hline CCR1 & $\begin{array}{l}\text { CCL3, CCL4, CCL5, CCL7, CCL14, } \\
\text { CCL15, CCL16, CCL23 }\end{array}$ \\
\hline CCR2 & CCL2, CCL7, CCL8, CCL12, CCL13 \\
\hline CCR3 & $\begin{array}{l}\text { CCL5, CCL7, CCL11, CCL13, CCL15, } \\
\text { CCL24, CCL26, CCL28 }\end{array}$ \\
\hline CCR4 & CCL2, CCL3, CCL5, CCL17, CCL22 \\
\hline CCR5 & CCL3, CCL4, CCL5, CCL8 \\
\hline CCR6 & CCL20 \\
\hline CCR7 & CCL19, CCL21 \\
\hline CCR8 & CCL1, CCL4, CCL17 \\
\hline CCR9 & CCL25 \\
\hline CCR10 & CCL27, CCL28 \\
\hline CCR11 & $\begin{array}{l}\text { CCL2, CCL7, CCL8, CCL12, CCL13, } \\
\text { CCL19, CCL21, CCL25 }\end{array}$ \\
\hline CX3CR1 & CX3CL1 \\
\hline XCR1 & XCL1, XCL2 \\
\hline
\end{tabular}

activation of the oncogenes that play a role in the regulation of the chemokines. Furthermore, deregulated expression of the transcription factors also affects the levels of chemokine and receptors regulated by them and promotes tumorigenesis. For example, the nuclear factorkappa B (NF-kappa B) family of transcription factors regulates the expression of many chemokines [10]. NFkappa B is constitutively activated in many tumors which leads to the constitutive expression of the chemokines regulated by them which then promotes tumorigenesis [10]. In this review, we will discuss the role of chemokines in tumor growth, progression, and metastasis.

\section{Chemokines in Senescence:}

Cellular senescence is a state of growth arrest that prevents unlimited proliferation of the cells [11]. Thus, cellular senescence is an important mechanism and it has attracted the attention of cancer scientists because of its ability to protect normal cells from transforming into cancer cells. Interestingly, oncogenes play an important role in inducing senescence [12]. Oncogene induced senescence (OIS) prevents unlimited cell proliferation and contributes toward preventing oncogenic transformation of the cells. Tumorigenesis is correlated with the secretion of cytokines and chemokines. Of note, some studies described below demonstrate that chemokines and their receptors promote senescence and delay tumorigenesis. IL-1 $\alpha$ plays an important role in the production of senescence associated chemokine CXCL8 along with IL-6 [13]. However, the loss of chemokine receptor CXCR2 reduces oncogene induced senescence along with the DNA damage response [14]. The activation of the transcription factors NF-kappa $\beta$ and $\mathrm{C} / \mathrm{EBP} \beta$ contributes to the secretion of CXCR2 binding chemokines and IL-6 $[14,15]$. Also, the reintroduction of the chemokine receptor CXCR2 leads to premature senescence by a p53 dependent mechanism [14]. This suggests that the CXCR2 along with the chemokines that bind to it promote cellular senescence and delay the process of oncogenesis. Low levels of CXCR2 are also found in head and squamous cell carcinoma [16]. However, mutations in CXCR2 or downregulation of CXCR2 expression may affect the ability of this chemokine receptor to induce senescence. One inactivating mutation of CXCR2 was found in NCI-H1395 cell line [17]. The inability to induce senescence by mutated CXCR2 may in fact promote tumorigenesis instead of blocking it. The above studies demonstrate the importance of CXCR2 in cellular senescence. Future studies should aim to determine the role of other chemokine receptors in cellular senescence.

\section{Chemokines in epithelial mesenchymal transformation}

An epithelial mesenchymal transition (EMT) is a biological process in which an epithelial cell undergoes biochemical changes to assume a mesenchymal cell phenotype that has increased capacity for migration and invasion [18]. Cancer cells acquire the mesenchymal phenotype to migrate, invade and metastasize. The chemokine CXCL8 is induced in cells that undergo TGF- $\beta$ driven EMT. The chemokine CXCL8 binds to the chemokine receptor CXCR1. Interestingly, CXCR1 is upregulated during EMT, thus demonstrating that the regulated expression of the chemokine CXCL8 along with its receptor CXCR1 is linked to EMT [19]. The treatment of rat hepatoma cells with TGF- $\beta$ promotes EMT phenotype in the cells. TGF- $\beta$ upregulates the expression of CXCR4 and the cells with a mesenchymal phenotype exhibit higher levels of CXCR4. Furthermore, the knockdown of CXCR4 in these cells or treatment 
with CXCR4 antagonist leads to a decrease in cell migration. This study suggests that CXCR4 induction after treatment with TGF- $\beta$ may play an important role in promoting EMT and thus aid in migration of these cells [20]. Another study also demonstrates the importance of CXCL8/CXCR1 in inducing EMT. The induction of EMT in human carcinoma cells overexpressing the transcription factor Brachyury is associated with increased secretion of multiple chemokines including CXCL8, CCL5 and CXCL1. However, the induction of CXCL8/CXCR1 axis is critical for EMT. The authors suggest that inhibiting CXCL8 signaling may help inhibit EMT by targeting the cells with the mesenchymal and invasive phenotype [21]. A recent study demonstrated that using a CXCR7 antagonist, CCX733 drastically reduced EMT in bladder cancer, which suggests the importance of CXCR7 in regulating EMT and in the development of bladder cancer [22]. Furthermore, in human colorectal carcinoma cells, the transcription factor SNAIL which plays a critical role in regulating EMT also regulates the expression of the chemokine CXCL8, which further demonstrates the importance of CXCL8 or IL-8 in the process of EMT in cancer [23]. These studies demonstrate the importance of chemokine receptor signaling in EMT which is an essential precursor for metastatic transformation of cancer cells. However, more studies are required to determine if targeting chemokine receptors can prevent EMT in various cancer types.

\section{Chemokines in tumor growth}

A number of studies have demonstrated the role of chemokines and chemokine receptors in tumor growth. Chemokines activate MAPK/ERK signaling pathway and thus promote tumor cell proliferation. The chemokine CXCL12 is involved in the growth of many cancers including acute lymphoblastic leukemia, chronic B cell leukemia, glioma, breast cancer, ovarian cancer, small cell lung cancer, non-Hodgkin's lymphoma and colon cancer [24-32]. Also, the chemokines CXCL1, CXCL2 and CXCL3 have been shown to play a role in the growth of pancreatic cancer, melanoma, lung cancer, adenocarcinoma and gastric cancer $[33,34]$. The chemokine receptor CXCR4 is over-expressed in many cancer types and is also involved in their proliferation. These cancers include melanoma, breast cancer, ovarian cancer, prostate cancer, lung cancer, glioma, renal cancer, B-cell chronic lymphocytic leukemia and thyroid cancer [28, 35-43]. The inhibition of the chemokine receptor CXCR4 leads to apoptosis in ovarian cancer, hepatoma and chronic lymphocytic leukemia cells, thus demonstrating the importance of this receptor in cell survival and proliferation [20, 44, 45]. Another chemokine receptor CXCR2 plays a vital role in the proliferation of esophageal cancer cells via GRO $\alpha$ and GRO $\beta$ [46]. Furthermore, the chemokine receptors for CXCL8: CXCR1 and CXCR2 are expressed in human gastric carcinoma cells and play a role in the proliferation of the cancer cells [47]. Overexpression of the receptors CXCR1 and CXCR2 in human melanoma cells increased cell proliferation and invasion in vitro and significantly enhanced tumor growth in vivo, thus demonstrating the importance of these receptors in melanoma tumor growth and progression [48]. The chemokine receptor CCR6 is expressed in colorectal cancer and stimulation by the chemokine ligand CCL20 promotes proliferation of colorectal cancer cells [49]. Furthermore, the expression of CXCR6 and its ligand CXCL16 in prostate cancer correlated with prognosis and CXCL16 enhanced the growth of CXCR6 expressing cancers $[50,51]$. CXCR6 along with CXCL16 mediates pro-tumorigenic effect on prostate cancer cells by inducing the migration and proliferation of tumor associated leukocytes [50]. The chemokine receptor CCR10 is expressed on melanoma cells. The exposure of the ligand CCL27 to the melanoma cells leads to activation of Akt and phosphatidylinositol-3-kinase and protects the cells from apoptosis. Thus, CCL27/CCR10 contributes to the growth of melanoma cells by the activation of PI3K/Akt pathway and by evading the host anti-tumor response [52]. The cells of squamous cell carcinoma of head and neck secrete the chemokines CCL19 and CCL21, which leads to the activation of CCR7 and promotes tumor growth and progression [53].

On the other hand, some chemokine receptors inhibit the proliferation of tumor cells. For example, the chemokine receptor CCR 1 can reduce the proliferation of human hepatocellular carcinoma cells [54]. Also, the inhibition of CCR5 increased the proliferation of breast cancer cells bearing wild type p53, which suggests that CCR5 inhibits breast cancer progression in a p53dependent manner [55]. Hence, given the pro- and antitumorigenic role of chemokines and its receptors, more studies are required to determine why some chemokine receptors facilitate tumor progression and others inhibit the growth of the tumors. Also, future studies should focus on elucidating the mechanism by which chemokines and chemokine receptors promote tumorigenesis, which could lead to targeted therapies.

\section{Chemokines in angiogenesis :}

Angiogenesis, the process of formation of new blood vessels from existing blood vessels is critical in tumor progression. Many chemokines and chemokine receptors play a vital role in angiogenesis. Chemokines can either stimulate the expression of pro-angiogenic factors or can bind to the chemokine receptors on the surface of endothelial cells and promote angiogenesis. The ELR motif present in the CXC chemokines plays an important role in promoting angiogenesis [56]. The CXC chemokines that have the ELR motif are potent angiogenic factors whereas chemokines without the ELR 
motif promote angiostasis [56]. The chemokines CXCL1, CXCL2, CXCL3, CXCL5, CXCL6, CXCL8, CXCL12, CCL2, CCL11 and CCL16 are angiogenic chemokines whereas CXCL4, CXCL9, CXCL10, CXCL11 and CXCL14 are angiostatic chemokines [57, 58].

The reduction in the levels of chemokines CXCL1, CXCL2 and CXCL3 in melanoma results in a decrease in tumor angiogenesis and tumor growth, suggesting the importance of these chemokines in angiogenesis $[59,60]$. The chemokine receptors CXCR1, CXCR2 and CXCR4 are expressed on the endothelial cells [61, 62]. The knockdown of CXCR1 and CXCR2 in human microvascular endothelial cells reduced migration, invasion and capillary like structure formation demonstrating the importance of these receptors in angiogenesis [61]. Also, the chemokine CXCL12 activates the chemokine receptor CXCR4 on endothelial cells, which promotes endothelial cell migration and proliferation in ovarian cancer cells [63]. The chemokine receptor CCR2 is also expressed by the endothelial cells [64]. A recent study demonstrates the role of CCR2-CCL2 axis in angiogenesis as well as tumor survival [65].

\section{Chemokines that inhibit angiogenesis:}

The chemokine receptor CXCR3 on human microvascular endothelial cells (HMVEC) blocks the proliferation of HMVEC in vitro and this effect is inhibited by anti-CXCR3 antibody. This study demonstrates the angiostatic effect of the chemokine receptor CXCR3 [66]. As mentioned previously, CXCL9, CXCL10 and CXCL11 (ELR ${ }^{-}$chemokines) are the anti-angiogenic chemokines and they inhibit angiogenesis via the chemokine receptor CXCR3-B [67, 68]. These chemokines inhibit angiogenesis in colon carcinoma, melanoma and uterine cervical cancers [69-71]. Also, the chemokine CXCL4 has been shown to have angiostatic effects [72]. The enhanced expression of the duffy antigen on endothelial cells suppresses the angiogenic effect of the CXC chemokines [73]. The fine balance between the angiogenic as well as angiostatic chemokines determines the fate of tumor cells by regulating angiogenesis.

Moreover, chemokines could also regulate angiogenesis indirectly. For example, CXCL6 and CXCL8, which are $\mathrm{ELR}^{+}$chemokines, promote angiogenesis by recruiting neutrophils [74]. The production of CXCL6 by the endothelial cells contributes to angiogenesis by attracting neutrophils that promote matrix degradation [75]. In a mouse model of pancreatic cancer, neutrophils contribute to angiogenesis by recruiting MMP-9 that activates vascular endothelial growth factor (VEGF) which is critical for angiogenesis [76]. Chemokines also promote angiogenesis by recruiting leukocytes, myeloid derived suppressor cells (MDSC), dendritic cells and tumor associated macrophages (TAM) [61, 77-79]. The chemokine CCL2 aids in the recruitment of these cells. The recruited TAMs and MDSCs could acquire characteristics of the endothelial cells and thus promote angiogenesis by being a part of the vasculature [80]. The recruited cells can also produce angiogenic factors such as vascular endothelial growth factor (VEGF), platelet derived growth factor (PDGF), transforming growth factor beta (TGF $\beta$ ), chemokines such as CXCL8, as well as matrix metalloproteinases such as MMP-2 and MMP-9 $[10,78,81]$.

\section{Chemokines in metastasis}

Metastasis is the process during which malignant tumor cells leave the primary tumor site, enter the blood stream or lymphatic system and migrate to other organs or sites in the body. Metastasis is a non-random, sequential, and organ-specific process. Certain organs, such as the liver, lungs, brain, lymph nodes, and bone marrow are common sites of metastasis, while others, such as the kidney, pancreas, and skin are rare [82]. Metastasis is the leading cause of death for a majority of solid tumors, and the ability to metastasize is one of the key features which distinguishes malignant tumors from benign lesions. While metastasis is a complex process involving various factors and small molecule regulators, studies have suggested that chemokines and their receptors play a key role in metastasis [38].

In normal physiological functions, homeostatic chemokines regulate the migration of leukocytes by recruiting specific populations of lymphoid cells to certain tissues in either innate or acquired immune responses. For instance, chemokine ligand CCL27 induces migration of leukocyte antigen CLA $+\mathrm{T}$ cells which express chemokine receptor CCR10 to the skin [83], and ligand CXCL12 in the bone marrow recruits hematopoietic stem cells which express the receptor CXCR4 [38]. While chemokines normally regulate the migration of immune cells, other cell types can take advantage of these chemokine "pathways" by expressing the appropriate receptor. Recent studies suggest that metastatic cancer cells simply co-opt these chemokine pathways to migrate to distant sites. Like normal leukocyte migration, tumor cell metastasis requires passage through vascular barriers, entry into the circulation, and extravasation at distant, non-random, organ-specific locations. Since leukocyte trafficking is regulated by chemokine receptors and their ligands, chemokines may also play a key role in initiating and regulating tumor cell migration and metastasis.

\section{a. CXCR4-CXCL12}

The CXCR4/CXCL12 axis is one of the most studied chemokine receptor axis and has been shown to play a vital role in metastasis. Studies show that metastatic breast cancers selectively express CXCR4 and migrate to organs that express high levels of its respective ligand CXCL12, also known as SDF-1 [38]. 
Chemokine receptor CXCR4 is consistently upregulated in metastatic breast cancer cell lines, lymph node metastases, and liver metastases while expression levels are undetectable in normal epithelial cells [38]. Its ligand CXCL12, meanwhile, is preferentially expressed in the most common sites of breast cancer metastasis, lung, brain, lymph nodes, liver, and bone marrow [38, 84]. This suggests that metastatic breast tumor cells selectively express CXCR4 which leads them to organs with high expression levels of CXCL12. Moreover, in vivo inhibition of CXCR4-CXCL12 interactions significantly reduces metastasis of breast tumor cells to the lymph node and lungs [38]. In addition, CXCR4-CXCL12 interactions also induce migratory responses that give tumor cells invasive ability. CXCR4-CXCL12 receptor-ligand interactions in breast cancer trigger actin polymerization which allows tumor cells to invade neighboring tissues and successfully metastasize [85], form pseudopodia, induce directional invasion of breast tumor cells [38]. Inhibition of CXCL12CXCR4 interactions using anti-CXCR4 or CXCL12 antibodies significantly impairs these migratory responses by $63-76 \%$ and $60-62 \%$, respectively [38].

Additional studies demonstrate that de novo expression of CXCR4 is sufficient to increase tumor invasion and metastasis in an organ-specific manner [86]. The murine B16 melanoma cell line experiences marked increase in metastasis to the lung when transfected with CXCR4 [86]. Inhibition of CXCR4 by the small molecule antagonist T22, however, stops the increase in metastasis of CXCR4-B16 cells [86]. Murkami et. al not only confirm the importance of CXCR4-CXCL12 in mediating metastasis, but they demonstrate that CXCR4 expression is sufficient for metastasis to occur [86].

Many metastatic human prostate cancers also express functional CXCR4 [87]. CXCR4 expression in prostate cancer enhances the invasive, metastatic ability of tumor cells in the presence of CXCL12 ligand, while inhibition of CXCR4 decreases metastatic ability [36, 87]. In comparison, presence of CXCL12 did not affect migratory ability of normal prostate epithelial cells [87]. Additionally, CXCR4 mediates prostate tumor cell adhesion through the $\alpha 5$ and $\beta 3$ integrins [88]. High expression levels of CXCR4 in human prostate cancers are associated with more frequent local recurrence and distant metastasis, suggesting that CXCR4 not only serves as a potential therapeutic target, but also a prognostic marker $[89,90]$.

Interestingly, high levels of CXCR4 are also observed in $\mathrm{CD}_{4} 4^{+} / \mathrm{CD} 133^{+}$prostate cancer stem cells (CSC) [91]. Since CSCs can initiate metastasis and help form new or recurrent tumors after initial treatment [92], the CXCR4-CXCL12 pathway may indirectly promote metastasis by maintaining and promoting stemness of CSCs [91]. Studies show that increased CXCR4 and CXCL12 expression promotes adhesion of CD133+/ CD44+ prostate CSCs to the extracellular protein fibronectin, important for distal organ seeding and initiation of secondary tumors [91]. In addition, CXCL12 causes activation of the PI3K pathway and promotes proliferation of $\mathrm{CXCR}^{+}$prostate CSCs [91]. Thus, the active CXCR4-CXCL12 pathway in prostate CSCs may indirectly promote metastasis by regulating cell adhesion, proliferation, differentiation potential, and tumorigenicity of prostate CSCs [91].

Studies show that CXCR4 plays an important role in metastasis of many cancers including breast [93-95], lung [96, 97], colorectal [98-100], gastric [101-103], ovarian [104, 105], prostate [106], pancreatic [107, 108], melanoma [100, 109-111], esophageal [112, 113], head and neck [114], bladder [115], osteosarcoma [116], neuroblastoma [117], glioblastoma [118, 119], and acute lymphoblastic leukemia [120]. In breast cancer, CXCR4 promotes metastasis to the lungs, liver, and lymph nodes [38]. In gastric cancer, studies show that CXCR4 promotes metastasis to the lymph nodes [102, 103]. Also, a study demonstrates that CXCR4 expression in esophageal cancer enhances metastasis to the lymph nodes and bone marrow [112]. Additional studies show that the CXCR4/ CXCL12 axis in ovarian cancer may promote peritoneal metastasis [104] as well as metastasis to the lymph nodes [121]. CXCR4 may also play a role in the metastasis of osteosarcoma to the lung [116] and neuroblastoma metastasis to the bone and bone marrow [117]. Thus, a number of studies have confirmed the important role of CXCR4 in metastasis.

\section{b. CCR7-CCL19/CCL21}

CCR7-mediated leukocyte migration is extremely important in normal immune responses. CCR7 recruits naive $T$ cells and activated dendritic cells to the lymph nodes, where they engage with one another and initiate adaptive immune responses [122]. CCR7 has two chemokine ligands: CCL19 and CCL21 [123, 124]; CCL21 regulates naive $\mathrm{T}$-cell homing to secondary lymphoid organs, while CCL19 activates T-cells [125]. Loss of CCL21 or inhibition of CCR7 gene results in significantly impaired T-cell homing to secondary lymphoid organs [126]. Many studies suggest that tumor cells co-opt the normal mechanism of CCR7-CCL21 leukocyte homing to metastasize to the lymph nodes. Studies show a majority of primary breast cancer tissues and metastatic cancer cells in the lymph nodes express CCR7, and there is significant correlation between CCR7 expression and lymph node metastasis. In addition, higher CCR7 expression is correlated with lower survival and worse prognosis in breast cancer patients [127]. Correlation between lymph node metastasis and CCR7 expression is observed in many cancers including esophageal squamous cell carcinoma [128], melanoma [129], non-small cell lung [130], head and neck [131], gastric [132], and colorectal [133].

De novo expression of CCR7 is sufficient to induce preferential metastasis to the lymph nodes in several 
human and mouse breast tumor cell lines that, without CCR7 expression, normally metastasize solely to the lung [134]. Expression of CCR7 in a non-metastatic B16 melanoma cell line also increases metastasis to the lymph nodes [135]. Interestingly, expression of CCR7 in B16 melanoma cells induces metastasis to the lymph nodes [135], while, as previously discussed, expression of CXCR4 in murine B16 cells increases metastasis to the lungs [86]. CCR7 expression in metastatic melanoma also induces in vivo growth toward lymphatic endothelial cells [136]. High CCR7 expression in human nonHodgkin's lymphoma induces metastatic spread through the PI3K/Akt signal pathway [137]. CCR7 expression also induces lymphatic spread in human pancreatic ductal adenocarcinoma [138]. In colon cancer, a study suggests that CCR7 promotes metastasis by upregulating matrix metalloproteinase-9 (MMP-9) expression [139].

Additional studies show that combined CCR7 and CXCR4 expression is also correlated with lymph nodes metastasis in breast cancer [38, 140, 141], gastric cancer [142], cervical cancer [143], and melanoma [38]. High levels of CCR7 are consistently expressed in breast tumor cells along with CXCR4, though CCR7 is also expressed in normal mammary epithelial cells [38]. Similar to CXCR4, CCR7-CCL21 interactions induces directional invasion of breast tumor cells, pseudopodia formation, and actin polymerization which increases the invasiveness of tumor cells [38]. Since both CCL21 and CXCL12 are highly expressed in the lymph nodes and receptor-ligand interactions of both chemokines promote invasiveness, it is likely that the two ligands work together to promote metastasis to the lymph nodes $[38,140]$.

CCR7 appears to play an especially important role in leukemias and lymphomas. Due to their lymphoid origin, many leukemias and lymphomas highly express CCR7 and experience frequent metastasis to the lymph nodes [144]. B cell malignancies with widespread dissemination to the lymph nodes, such as B-cell chronic lymphocytic leukemia (B-CLL) [145], express high levels of CCR7, which mediates B cell entry into the lymphoid tissue, while neoplasms that experience little metastasis to the lymph nodes, such as multiple myeloma or hairy cell leukemia [145], express low levels of CCR7 and low to moderate levels of CXCR4 [144].

In addition, studies suggest that CCR7 mediates metastasis of T-cell leukemia to the central nervous system (CNS). Buonomici et al. show that Notch1 signaling, active and mutated in most T-ALL patients [146], upregulates CCR7 expression in T-ALL. Expressing oncogenic Notch 1 causes mice to develop characteristic pathological features of T-ALL and infiltration of the leptomeningeal spaces of the brain, demonstrating that oncogenic Notch1 is capable of inducing T-ALL and targeting transformed cells to the CNS [147]. Analysis of primary T-ALL samples as well as T-ALL cell-lines containing Notch1-activating mutations have CCR7 upregulation caused by Notch1 signaling [147]. CCR7 also plays an important role in squamous cell carcinoma of the head and neck (SCCHN). Studies show CCR7 upregulation in SCCHN is correlated with lower survival due to increased metastasis [148]. CCR7 mediates SCCHN metastasis by activating integrin $\alpha v \beta 3$ [139], which facilitates adhesion of cancer cells to or migration through the extracellular matrix. In additions, CCR7 mediates cell survival of metastatic SCCHN cell lines by phosphorylation of Akt in a PI3K-dependent fashion [149151]. CCR7-CCL19 activation of the PI3K/Akt/mTOR signal pathway subsequently activates the downstream signal molecule NF-кB [149]. CCR7-CCL19 interactions induce phosphorylation of $\mathrm{I} \kappa \mathrm{B} \alpha$, causing $\mathrm{NF}-\kappa \mathrm{B}$ to translocate to the nucleus and raise the DNA-binding capacity of NF- $\kappa \mathrm{B}$ [149]. Inhibition of CCR7, PI3K, Akt and mTOR successfully stops phosphorylation and DNA-binding. Moreover, CCR7 and NF- $\mathrm{kB}$ expression in patient samples directly correlates and is also associated with increased lymph node metastasis and clinical progression [149]. Thus, CCR7 enhances survival of metastatic SCCHN by activating NF- $\mathrm{KB}$ via the PI3K/Akt/ mTOR signal pathway [149].

\section{c. CCR9-CCL25}

In normal physiological conditions, CCR9 functions in mucosal immunity and lymphocyte trafficking during T-cell development [152]. Its ligand CCL25, or TECK, is expressed in the small intestine and thymus [153]. As migration of CCR9-postive lymphocytes to the small intestine relies on chemoattractive effects of CCL25 and the action of $\alpha \beta$ integrin heterodimers, studies suggest CCR9-CCL25 also mediates melanoma metastasis to the small intestine. Most tumors of the small intestine, which are rare and account for just $2 \%$ of all gastrointestinal tumors, are metastasis from melanoma [154-156]. Studies investigating melanoma metastasis demonstrate that CCR9 is highly expressed in melanoma cells and small intestinal metastasis [157] and that functional expression of CCR9 on melanoma cells mediates migration to the small intestine, explaining their preferential migration to the small intestine [158].

Some breast cancer cell lines also express CCR9 [159]. A recent study suggests that CCR9 may promote metastasis in breast cancer by enhancing cell migration, increasing matrix-metalloproteinase-9 (MMP-9) expression via CCL25 and supporting tumor cell survival in metastatic sites [159]. Certain ovarian cancer cell lines and tumors also express CCR9 [160]; however, further research is needed to elucidate the role of CCR9 in other cancers and to determine the mechanism by which it promotes metastasis.

\section{d. CCR10-CCL27/CCL28}

The chemokine receptor CCR10 binds ligand CCL27, which is highly expressed in both normal and inflammatory skin [161]. In the skin, CCL27 recruits 
leukocyte antigen CLA + T cells which express chemokine receptor CCR10 [83]. Studies show that malignant melanoma expresses high levels of CCR10 in addition to CXCR4 and CCR7 [162]. Melanoma shares a similar metastatic phenotype to breast cancer, which also expresses high levels of CXCR4 and CCR7, but unlike breast cancer, experiences frequent metastasis to the skin [38]. Given the role of CCR10-CCL27 in leukocyte migration to the skin, it is likely that CCR10 expression in melanoma induces metastasis to the skin. However, another study suggests that CCR10 expression in melanoma promotes metastasis to the lymph nodes in addition to enhancing invasion, growth, and immune escape of tumor cells [163]. CCR10 and its ligand CCL27 are also upregulated in cutaneous squamous cell carcinoma, and its expression is correlated with progression of the cancer [164].

\section{e. CXCR3-CXCL9, CXCL10, CXCL11}

CXCR3 expression in cutaneous malignant melanoma correlates with tumor progression [165], and is constitutively expressed in several human melanoma cell lines and mouse B16F10 melanoma cell line [166]. Loss of CXCR3 expression in mouse B16F10 melanoma decreases metastasis to the lymph nodes by $\sim 15 \%$, suggesting that CXCR3 may play a role in lymph node metastasis [166]. CXCR3 is also constitutively expressed in lung adenocarcinoma; however, CXCR3 expression is not significantly correlated with lymph node metastasis [167]. Some colon cancers also constitutively express CXCR3, and patients that express CXCR3 in tumors experience worse prognosis than those without CXCR3 [168]. Kawada et. al demonstrate that expressing CXCR3 in a colon cancer cell line increases in vivo metastasis to the lymph nodes, but not to the liver or lungs [168]. Cambien et. al, on the other hand, report that in vivo activation of CXCR3 increases metastasis to the lungs [169]. Additional studies suggest that CXCR3 activation in colon cancer synergistically enhances CXCR4-mediated tumor cell migration to the lymph nodes, liver, and lungs [170]. Thus, the function of CXCR3 in colon cancer may depend on its cooperation with other expressed chemokine receptors such as CXCR4 and CCR7.

In osteosarcoma, studies suggest that CXCR3 and its ligands induce metastasis to the lungs and later stimulate growth and expansion of the metastases [171]. Treating mice with CXCR3 antagonist AMG487 significantly decreases lung metastases and reduces tumor expansion within the lungs in two murine models of osteosarcoma [171]. CXCR3 inhibition similarly reduces lung metastasis in a metastatic breast cancer murine model [172]. These studies suggest that CXCR3 may play an important role in mediating metastasis to the lungs.

\section{f. CXCR5-CXCL13}

CXCR5, along with CXCR4 and CCR7, also helps regulate $\mathrm{B}$ cell entry into secondary lymphoid tissues and their homing to $\mathrm{T}$ cell and B cell zones within lymphoid tissues [173, 174]. Studies show certain lymphomas express CXCR5 along with CCR7 in malignancies which experience frequent metastasis to the lymph nodes suggesting a role of CXCR5 in lymph node metastasis [144]. The expression of CXCR5 is especially high in chronic lymphocytic leukemia and mantle lymphoma [144]. Consistent CXCR5 upregulation is also observed in squamous cell carcinomas, suggesting that CXCR5/ CXCL13 interactions may serve as a novel complementary pathway mediating metastasis to the lymph nodes [131]. CXCR5 may also mediate metastasis of neuroblastoma cells to the bone marrow through interactions with CCL16 expressing stromal cells [175]. However, further research is required to elucidate the role of CXCR5 in other malignancies and determine the mechanisms by which it promotes metastasis.

\section{Chemokine Receptors and Brain Metastasis:}

Brain metastasis is one of the major causes of cancer related deaths in patients. To develop novel therapeutic approaches for patients with brain metastasis, it is important to understand the biology of the metastatic lesions in the brain and the role of the brain microenvironment in promoting brain metastasis. Since chemokine receptors have already been shown to play a role in metastasis, there is little doubt about their role in brain metastasis as well. The chemokine receptor CXCR4 is overexpressed in brain metastatic sections of patients with non-small cell lung cancer [176, 177]. Also, CXCR4 is overexpressed in brain metastatic sections of patients with colorectal cancer [165]. Furthermore, another study demonstrates the importance of CXCR4 in promoting invasion through human brain microvascular endothelial cells in breast cancer in vitro [178]. The chemokine receptor $\mathrm{CX} 3 \mathrm{CR} 1$ has been also associated with brain metastasis in axillary node positive primary breast cancer [179]. Finally, CCR4 has been shown to play a role in melanoma metastasis to the brain [180].

The chemokine receptor CCR7 interacts with CCL19 and mediates T-cell acute lymphoblastic leukemia (ALL) metastasis to the central nervous system. A lymphoid Rag2 ${ }^{--}$IL2 $\mathrm{rg}^{-/}$mouse transplanted with CCR7positive $\left(\mathrm{CEM} / \mathrm{CCR}^{+}\right)$human T-ALL cell line results in CNS infiltration and reduced survival in comparison to mice transplanted with a CCR7-deficient (DND41/ CCR7-) T-ALL cell line. Meanwhile, expression of CCR7 in DND41 cells is sufficient to induce brain and spinal cord infiltration, while silencing CCR7 successfully inhibits T-ALL CNS metastasis. However, CCR7 appears to regulate CNS infiltration only in Notch-1-induced T-cell malignancy, as CCR7 inhibition fails to suppress CNS infiltration in B-cell models. Overall, these data demonstrate that in addition to promoting metastasis to the lymph nodes, CCR7 also regulates metastasis of T-cell leukemia to the brain and central nervous system [147]. 
These studies suggest the important role of the chemokine receptors in brain metastasis.

\section{CONCLUSION}

A number of studies posit the role of chemokine and chemokine receptors in various stages of tumor progression. Chemokines and their receptors facilitate tumor growth by promoting EMT as well as angiogenesis. The expression of certain chemokine receptors on the surface of the cancer cells promotes metastasis and organ specific metastasis. CXCR4 is one of the well-studied chemokine receptors. In 2010, the U.S Food and Drug Administration approved the CXCR4 inhibitor plerixafor in patients with non-Hodgkin lymphoma (NHL) and multiple myeloma (MM). Moreover, while some chemokine receptors, such as CXCR4 and CCR7, have been extensively studied, additional studies are needed to examine the role of other chemokines in tumor progression and metastasis. Future studies should focus on elucidating the molecular mechanism and signaling pathways through which chemokines mediate tumor progression and metastasis. Furthermore, it will be interesting to explore the prospect of a combination therapy of chemokine receptor antagonists with other chemotherapeutic agents to determine the effect on survival in patients. Ultimately, chemokines and chemokine receptors may serve as useful therapeutic targets in preventing tumor progression and metastasis and thus help in improving survival in cancer patients.

\section{ACKNOWLEDGEMENTS:}

This work was supported by the grants NCI (RO1CA138587), the NIH (RO1NS077388) and the National Institute of Neurological Disorders and Stroke (UO1NS069997) awarded to M.L.

\section{Conflict of interest :}

The authors have no conflict of interest

\section{REFERENCES}

1. Raman D, Sobolik-Delmaire $\mathrm{T}$ and Richmond A. Chemokines in health and disease. Exp. Cell Res. 2011; 317(5):575-589.

2. Zlotnik A and Yoshie O. Chemokines: a new classification system and their role in immunity. Immunity. 2000; 12(2):121-127.

3. Murphy PM, Baggiolini M, Charo IF, Hebert CA, Horuk R, Matsushima K, Miller LH, Oppenheim JJ and Power CA. International union of pharmacology. XXII. Nomenclature for chemokine receptors. Pharmacol. Rev. 2000; 52(1):145176.
4. Schall TJ and Proudfoot AE. Overcoming hurdles in developing successful drugs targeting chemokine receptors. Nat Rev Immunol. 2011; 11(5):355-363.

5. Olson TS and Ley K. Chemokines and chemokine receptors in leukocyte trafficking. Am. J. Physiol. 2002; 283(1):R728.

6. Proost P, Struyf S and Van Damme J. Natural posttranslational modifications of chemokines. Biochem. Soc. Trans. 2006; 34(Pt 6):997-1001.

7. Loos T, Mortier A, Gouwy M, Ronsse I, Put W, Lenaerts JP, Van Damme J and Proost P. Citrullination of CXCL10 and CXCL11 by peptidylarginine deiminase: a naturally occurring posttranslational modification of chemokines and new dimension of immunoregulation. Blood. 2008; 112(7):2648-2656.

8. Struyf S, Noppen S, Loos T, Mortier A, Gouwy M, Verbeke H, Huskens D, Luangsay S, Parmentier M, Geboes K, Schols D, Van Damme J and Proost P. Citrullination of CXCL12 differentially reduces CXCR4 and CXCR7 binding with loss of inflammatory and anti-HIV-1 activity via CXCR4. J. Immunol. 2009; 182(1):666-674.

9. Loos T, Opdenakker G, Van Damme J and Proost P. Citrullination of CXCL8 increases this chemokine's ability to mobilize neutrophils into the blood circulation. Haematologica. 2009; 94(10):1346-1353.

10. Richmond A. Nf-kappa B, chemokine gene transcription and tumour growth. Nat Rev Immunol. 2002; 2(9):664-674.

11. Collado M, Blasco MA and Serrano M. Cellular senescence in cancer and aging. Cell. 2007; 130(2):223-233.

12. Mooi WJ and Peeper DS. Oncogene-induced cell senescence--halting on the road to cancer. N. Engl. J. Med. 2006; 355(10):1037-1046.

13. Orjalo AV, Bhaumik D, Gengler BK, Scott GK and Campisi J. Cell surface-bound IL-1alpha is an upstream regulator of the senescence-associated IL-6/IL-8 cytokine network. Proc. Natl. Acad. Sci. U. S. A. 2009; 106(40):17031-17036.

14. Acosta JC, O'Loghlen A, Banito A, Guijarro MV, Augert A, Raguz S, Fumagalli M, Da Costa M, Brown C, Popov N, Takatsu Y, Melamed J, d'Adda di Fagagna F, Bernard D, Hernando E and Gil J. Chemokine signaling via the CXCR2 receptor reinforces senescence. Cell. 2008; 133(6):10061018.

15. Kuilman T, Michaloglou C, Vredeveld LC, Douma S, van Doorn R, Desmet CJ, Aarden LA, Mooi WJ and Peeper DS. Oncogene-induced senescence relayed by an interleukindependent inflammatory network. Cell. 2008; 133(6):10191031.

16. Ginos MA, Page GP, Michalowicz BS, Patel KJ, Volker SE, Pambuccian SE, Ondrey FG, Adams GL and Gaffney PM. Identification of a gene expression signature associated with recurrent disease in squamous cell carcinoma of the head and neck. Cancer Res. 2004; 64(1):55-63.

17. Acosta JC and Gil J. A role for CXCR2 in senescence, but what about in cancer? Cancer Res. 2009; 69(6):2167-2170. 
18. Kalluri R and Weinberg RA. The basics of epithelialmesenchymal transition. J. Clin. Invest. 2009; 119(6):14201428.

19. Bates RC, DeLeo MJ, 3rd and Mercurio AM. The epithelialmesenchymal transition of colon carcinoma involves expression of IL-8 and CXCR-1-mediated chemotaxis. Exp. Cell Res. 2004; 299(2):315-324.

20. Bertran E, Caja L, Navarro E, Sancho P, Mainez J, Murillo MM, Vinyals A, Fabra A and Fabregat I. Role of CXCR4/ SDF-1 alpha in the migratory phenotype of hepatoma cells that have undergone epithelial-mesenchymal transition in response to the transforming growth factor-beta. Cell. Signal. 2009; 21(11):1595-1606.

21. Fernando RI, Castillo MD, Litzinger M, Hamilton DH and Palena C. IL- 8 signaling plays a critical role in the epithelial-mesenchymal transition of human carcinoma cells. Cancer Res.; 71(15):5296-5306.

22. Hao M, Zheng J, Hou K, Wang J, Chen X, Lu X, Bo J, Xu $\mathrm{C}$, Shen K and Wang J. Role of chemokine receptor CXCR7 in bladder cancer progression. Biochem. Pharmacol; 84(2):204-214.

23. Hwang WL, Yang MH, Tsai ML, Lan HY, Su SH, Chang SC, Teng HW, Yang SH, Lan YT, Chiou SH and Wang HW. SNAIL regulates interleukin-8 expression, stem cell-like activity, and tumorigenicity of human colorectal carcinoma cells. Gastroenterology. 141(1):279-291, 291 e271-275.

24. Hall JM and Korach KS. Stromal cell-derived factor 1, a novel target of estrogen receptor action, mediates the mitogenic effects of estradiol in ovarian and breast cancer cells. Mol. Endocrinol. 2003; 17(5):792-803.

25. Scotton CJ, Wilson JL, Milliken D, Stamp G and Balkwill FR. Epithelial cancer cell migration: a role for chemokine receptors? Cancer Res. 2001; 61(13):4961-4965.

26. Zhou Y, Larsen PH, Hao C and Yong VW. CXCR4 is a major chemokine receptor on glioma cells and mediates their survival. J. Biol. Chem. 2002; 277(51):49481-49487.

27. Barbero S, Bonavia R, Bajetto A, Porcile C, Pirani P, Ravetti JL, Zona GL, Spaziante R, Florio T and Schettini G. Stromal cell-derived factor 1alpha stimulates human glioblastoma cell growth through the activation of both extracellular signal-regulated kinases $1 / 2$ and Akt. Cancer Res. 2003; 63(8):1969-1974.

28. Kijima T, Maulik G, Ma PC, Tibaldi EV, Turner RE, Rollins B, Sattler M, Johnson BE and Salgia R. Regulation of cellular proliferation, cytoskeletal function, and signal transduction through CXCR4 and c-Kit in small cell lung cancer cells. Cancer Res. 2002; 62(21):6304-6311.

29. Bertolini F, Dell'Agnola C, Mancuso P, Rabascio C, Burlini A, Monestiroli S, Gobbi A, Pruneri G and Martinelli G. CXCR4 neutralization, a novel therapeutic approach for non-Hodgkin's lymphoma. Cancer Res. 2002; 62(11):31063112.

30. Juarez J, Bradstock KF, Gottlieb DJ and Bendall LJ. Effects of inhibitors of the chemokine receptor CXCR4 on acute lymphoblastic leukemia cells in vitro. Leukemia. 2003; 17(7):1294-1300.

31. Burger JA, Tsukada N, Burger M, Zvaifler NJ, Dell'Aquila $\mathrm{M}$ and Kipps TJ. Blood-derived nurse-like cells protect chronic lymphocytic leukemia B cells from spontaneous apoptosis through stromal cell-derived factor-1. Blood. 2000; 96(8):2655-2663.

32. Sebolt-Leopold JS, Dudley DT, Herrera R, Van Becelaere K, Wiland A, Gowan RC, Tecle H, Barrett SD, Bridges A, Przybranowski S, Leopold WR and Saltiel AR. Blockade of the MAP kinase pathway suppresses growth of colon tumors in vivo. Nat. Med. 1999; 5(7):810-816.

33. Richmond A and Thomas HG. Purification of melanoma growth stimulatory activity. J. Cell. Physiol. 1986; 129(3):375-384.

34. Bendall L. Chemokines and their receptors in disease. Histol. Histopathol. 2005; 20(3):907-926.

35. Balkwill F. Cancer and the chemokine network. Nature reviews. 2004; 4(7):540-550.

36. Darash-Yahana M, Pikarsky E, Abramovitch R, Zeira E, Pal B, Karplus R, Beider K, Avniel S, Kasem S, Galun E and Peled A. Role of high expression levels of CXCR4 in tumor growth, vascularization, and metastasis. FASEB J. 2004; 18(11):1240-1242.

37. Teicher BA and Fricker SP. CXCL12 (SDF-1)/CXCR4 pathway in cancer. Clin. Cancer Res.; 16(11):2927-2931.

38. Muller A, Homey B, Soto H, Ge N, Catron D, Buchanan ME, McClanahan T, Murphy E, Yuan W, Wagner SN, Barrera JL, Mohar A, Verastegui E and Zlotnik A. Involvement of chemokine receptors in breast cancer metastasis. Nature. 2001; 410(6824):50-56.

39. Sun Y, Cheng Z, Ma L and Pei G. Beta-arrestin2 is critically involved in CXCR4-mediated chemotaxis, and this is mediated by its enhancement of p38 MAPK activation. J. Biol. Chem. 2002; 277(51):49212-49219.

40. Staller P, Sulitkova J, Lisztwan J, Moch H, Oakeley EJ and Krek W. Chemokine receptor CXCR4 downregulated by von Hippel-Lindau tumour suppressor pVHL. Nature. 2003; 425(6955):307-311.

41. Koshiba T, Hosotani R, Miyamoto Y, Ida J, Tsuji S, Nakajima S, Kawaguchi M, Kobayashi H, Doi R, Hori T, Fujii $\mathrm{N}$ and Imamura M. Expression of stromal cell-derived factor 1 and CXCR4 ligand receptor system in pancreatic cancer: a possible role for tumor progression. Clin. Cancer Res. 2000; 6(9):3530-3535.

42. Rempel SA, Dudas S, Ge S and Gutierrez JA. Identification and localization of the cytokine SDF1 and its receptor, CXC chemokine receptor 4 , to regions of necrosis and angiogenesis in human glioblastoma. Clin. Cancer Res. 2000; 6(1):102-111.

43. Barretina J, Junca J, Llano A, Gutierrez A, Flores A, Blanco J, Clotet B and Este JA. CXCR4 and SDF-1 expression in B-cell chronic lymphocytic leukemia and stage of the 
disease. Ann. Hematol. 2003; 82(8):500-505.

44. Nomiyama H, Osada $\mathrm{N}$ and Yoshie O. The evolution of mammalian chemokine genes. Cytokine Growth Factor Rev.; 21(4):253-262.

45. Messmer D, Fecteau JF, O'Hayre M, Bharati IS, Handel TM and Kipps TJ. Chronic lymphocytic leukemia cells receive RAF-dependent survival signals in response to CXCL12 that are sensitive to inhibition by sorafenib. Blood. 117(3):882-889.

46. Wang B, Hendricks DT, Wamunyokoli F and Parker MI. A growth-related oncogene/CXC chemokine receptor 2 autocrine loop contributes to cellular proliferation in esophageal cancer. Cancer Res. 2006; 66(6):3071-3077.

47. Kitadai Y, Haruma K, Mukaida N, Ohmoto Y, Matsutani N, Yasui W, Yamamoto S, Sumii K, Kajiyama G, Fidler IJ and Tahara E. Regulation of disease-progression genes in human gastric carcinoma cells by interleukin 8. Clin. Cancer Res. 2000; 6(7):2735-2740.

48. Singh S, Nannuru KC, Sadanandam A, Varney ML and Singh RK. CXCR1 and CXCR2 enhances human melanoma tumourigenesis, growth and invasion. Br. J. Cancer. 2009; 100(10):1638-1646.

49. Ghadjar P, Rubie C, Aebersold DM and Keilholz U. The chemokine CCL20 and its receptor CCR6 in human malignancy with focus on colorectal cancer. Int. J. Cancer. 2009; 125(4):741-745.

50. Darash-Yahana M, Gillespie JW, Hewitt SM, Chen YY, Maeda S, Stein I, Singh SP, Bedolla RB, Peled A, Troyer DA, Pikarsky E, Karin M and Farber JM. The chemokine CXCL16 and its receptor, CXCR6, as markers and promoters of inflammation-associated cancers. PloS one. 2009; 4(8):e6695.

51. Ha HK, Lee W, Park HJ, Lee SD, Lee JZ and Chung MK. Clinical significance of CXCL16/CXCR6 expression in patients with prostate cancer. Molecular medicine reports. 2011; 4(3):419-424.

52. Murakami T, Cardones AR, Finkelstein SE, Restifo NP, Klaunberg BA, Nestle FO, Castillo SS, Dennis PA and Hwang ST. Immune evasion by murine melanoma mediated through CC chemokine receptor-10. J. Exp. Med. 2003; 198(9):1337-1347.

53. Wang J, Seethala RR, Zhang Q, Gooding W, van Waes $\mathrm{C}$, Hasegawa $\mathrm{H}$ and Ferris RL. Autocrine and paracrine chemokine receptor 7 activation in head and neck cancer: implications for therapy. J. Natl. Cancer Inst. 2008; 100(7):502-512.

54. Lu P, Nakamoto Y, Nemoto-Sasaki Y, Fujii C, Wang H, Hashii M, Ohmoto Y, Kaneko S, Kobayashi K and Mukaida N. Potential interaction between CCR1 and its ligand, CCL3, induced by endogenously produced interleukin-1 in human hepatomas. Am. J. Pathol. 2003; 162(4):1249-1258.

55. Manes S, Mira E, Colomer R, Montero S, Real LM, GomezMouton C, Jimenez-Baranda S, Garzon A, Lacalle RA, Harshman K, Ruiz A and Martinez AC. CCR5 expression influences the progression of human breast cancer in a p53dependent manner. J. Exp. Med. 2003; 198(9):1381-1389.

56. Strieter RM, Polverini PJ, Kunkel SL, Arenberg DA, Burdick MD, Kasper J, Dzuiba J, Van Damme J, Walz A, Marriott D and et al. The functional role of the ELR motif in CXC chemokine-mediated angiogenesis. J. Biol. Chem. 1995; 270(45):27348-27357.

57. Kiefer F and Siekmann AF. The role of chemokines and their receptors in angiogenesis. Cellular and molecular life sciences : CMLS. 2011; 68(17):2811-2830.

58. Mehrad B, Keane MP and Strieter RM. Chemokines as mediators of angiogenesis. Thromb. Haemost. 2007; 97(5):755-762.

59. Luan J, Shattuck-Brandt R, Haghnegahdar H, Owen JD, Strieter R, Burdick M, Nirodi C, Beauchamp D, Johnson KN and Richmond A. Mechanism and biological significance of constitutive expression of MGSA/GRO chemokines in malignant melanoma tumor progression. J. Leukoc. Biol. 1997; 62(5):588-597.

60. Owen JD, Strieter R, Burdick M, Haghnegahdar H, Nanney L, Shattuck-Brandt R and Richmond A. Enhanced tumorforming capacity for immortalized melanocytes expressing melanoma growth stimulatory activity/growth-regulated cytokine beta and gamma proteins. Int. J. Cancer. 1997; 73(1):94-103.

61. Singh S, Wu S, Varney M, Singh AP and Singh RK. CXCR1 and CXCR2 silencing modulates CXCL8dependent endothelial cell proliferation, migration and capillary-like structure formation. Microvasc. Res. 2011; 82(3):318-325.

62. Kryczek I, Lange A, Mottram P, Alvarez X, Cheng P, Hogan M, Moons L, Wei S, Zou L, Machelon V, Emilie D, Terrassa M, Lackner A, Curiel TJ, Carmeliet P and Zou W. CXCL12 and vascular endothelial growth factor synergistically induce neoangiogenesis in human ovarian cancers. Cancer Res. 2005; 65(2):465-472.

63. Yang L, Huang J, Ren X, Gorska AE, Chytil A, Aakre M, Carbone DP, Matrisian LM, Richmond A, Lin PC and Moses HL. Abrogation of TGF beta signaling in mammary carcinomas recruits $\mathrm{Gr}-1+\mathrm{CD} 11 \mathrm{~b}+$ myeloid cells that promote metastasis. Cancer cell. 2008; 13(1):23-35.

64. Weber KS, Nelson PJ, Grone HJ and Weber C. Expression of CCR2 by endothelial cells : implications for MCP-1 mediated wound injury repair and In vivo inflammatory activation of endothelium. Arterioscler. Thromb. Va c. Biol. 1999; 19(9):2085-2093.

65. Izhak L, Wildbaum G, Jung S, Stein A, Shaked Y and Karin N. Dissecting the autocrine and paracrine roles of the CCR2-CCL2 axis in tumor survival and angiogenesis. PloS one. 2012; 7(1):e28305.

66. Romagnani P, Annunziato F, Lasagni L, Lazzeri E, Beltrame C, Francalanci M, Uguccioni M, Galli G, Cosmi L, Maurenzig L, Baggiolini M, Maggi E, Romagnani S and Serio M. Cell cycle-dependent expression of CXC 
chemokine receptor 3 by endothelial cells mediates angiostatic activity. J. Clin. Invest. 2001; 107(1):53-63.

67. Lasagni L, Francalanci M, Annunziato F, Lazzeri E, Giannini S, Cosmi L, Sagrinati C, Mazzinghi B, Orlando C, Maggi E, Marra F, Romagnani S, Serio M and Romagnani P. An alternatively spliced variant of CXCR3 mediates the inhibition of endothelial cell growth induced by IP-10, Mig, and I-TAC, and acts as functional receptor for platelet factor 4. J. Exp. Med. 2003; 197(11):1537-1549.

68. Ehlert JE, Addison CA, Burdick MD, Kunkel SL and Strieter RM. Identification and partial characterization of a variant of human CXCR3 generated by posttranscriptional exon skipping. J. Immunol. 2004; 173(10):6234-6240.

69. Naschberger E, Croner RS, Merkel S, Dimmler A, Tripal P, Amann KU, Kremmer E, Brueckl WM, Papadopoulos T, Hohenadl C, Hohenberger W and Sturzl M. Angiostatic immune reaction in colorectal carcinoma: Impact on survival and perspectives for antiangiogenic therapy. Int. J. Cancer. 2008; 123(9):2120-2129.

70. Sato E, Fujimoto J, Toyoki H, Sakaguchi H, Alam SM, Jahan I and Tamaya T. Expression of IP-10 related to angiogenesis in uterine cervical cancers. Br. J. Cancer. 2007; 96(11):1735-1739.

71. Yang $\mathrm{J}$ and Richmond A. The angiostatic activity of interferon-inducible protein-10/CXCL10 in human melanoma depends on binding to CXCR3 but not to glycosaminoglycan. Mol Ther. 2004; 9(6):846-855.

72. Maione TE, Gray GS, Petro J, Hunt AJ, Donner AL, Bauer SI, Carson HF and Sharpe RJ. Inhibition of angiogenesis by recombinant human platelet factor-4 and related peptides. Science. 1990; 247(4938):77-79.

73. Du J, Luan J, Liu H, Daniel TO, Peiper S, Chen TS, Yu Y, Horton LW, Nanney LB, Strieter RM and Richmond A. Potential role for Duffy antigen chemokine-binding protein in angiogenesis and maintenance of homeostasis in response to stress. J. Leukoc. Biol. 2002; 71(1):141-153.

74. Tazzyman S, Lewis CE and Murdoch C. Neutrophils: key mediators of tumour angiogenesis. Int. J. Exp. Pathol. 2009; 90(3):222-231.

75. Gijsbers K, Gouwy M, Struyf S, Wuyts A, Proost P, Opdenakker G, Penninckx F, Ectors N, Geboes K and Van Damme J. GCP-2/CXCL6 synergizes with other endothelial cell-derived chemokines in neutrophil mobilization and is associated with angiogenesis in gastrointestinal tumors. Exp. Cell Res. 2005; 303(2):331-342.

76. Nozawa H, Chiu $\mathrm{C}$ and Hanahan D. Infiltrating neutrophils mediate the initial angiogenic switch in a mouse model of multistage carcinogenesis. Proc. Natl. Acad. Sci. U. S. A. 2006; 103(33):12493-12498.

77. Lazennec G and Richmond A. Chemokines and chemokine receptors: new insights into cancer-related inflammation. Trends in molecular medicine. 2010; 16(3):133-144.

78. Mantovani A, Schioppa T, Porta C, Allavena P and Sica A. Role of tumor-associated macrophages in tumor progression and invasion. Cancer metastasis reviews. 2006; 25(3):315322 .

79. Lewis CE and Pollard JW. Distinct role of macrophages in different tumor microenvironments. Cancer Res. 2006; 66(2):605-612.

80. Rehman J, Li J, Orschell CM and March KL. Peripheral blood "endothelial progenitor cells" are derived from monocyte/macrophages and secrete angiogenic growth factors. Circulation. 2003; 107(8):1164-1169.

81. Sozzani S, Rusnati M, Riboldi E, Mitola S and Presta M. Dendritic cell-endothelial cell cross-talk in angiogenesis. Trends in immunology. 2007; 28(9):385-392.

82. Zlotnik A, Burkhardt AM and Homey B. Homeostatic chemokine receptors and organ-specific metastasis. Nat Rev Immunol. 2011; 11(9):597-606.

83. Homey B, Alenius H, Muller A, Soto H, Bowman EP, Yuan W, McEvoy L, Lauerma AI, Assmann T, Bunemann E, Lehto M, Wolff H, Yen D, Marxhausen H, To W, Sedgwick J, et al. CCL27-CCR10 interactions regulate T cell-mediated skin inflammation. Nat. Med. 2002; 8(2):157165.

84. Bruce J, Carter DC and Fraser J. Patterns of recurrent disease in breast cancer. Lancet. 1970; 1(7644):433-435.

85. Verschueren H, Van der Taelen I, Dewit J, De Braekeleer $\mathrm{J}$ and De Baetselier P. Metastatic competence of BW5147 T-lymphoma cell lines is correlated with in vitro invasiveness, motility and F-actin content. J. Leukoc. Biol. 1994; 55(4):552-556.

86. Murakami T, Maki W, Cardones AR, Fang H, Tun Kyi A, Nestle FO and Hwang ST. Expression of CXC chemokine receptor-4 enhances the pulmonary metastatic potential of murine B16 melanoma cells. Cancer Res. 2002; 62(24):7328-7334.

87. Arya M, Patel HR, McGurk C, Tatoud R, Klocker H, Masters $\mathrm{J}$ and Williamson $\mathrm{M}$. The importance of the CXCL12-CXCR4 chemokine ligand-receptor interaction in prostate cancer metastasis. J. Exp. Ther. Oncol. 2004; 4(4):291-303.

88. Engl T, Relja B, Marian D, Blumenberg C, Muller I, Beecken WD, Jones J, Ringel EM, Bereiter-Hahn J, Jonas D and Blaheta RA. CXCR4 chemokine receptor mediates prostate tumor cell adhesion through alpha5 and beta3 integrins. Neoplasia. 2006; 8(4):290-301.

89. Sun YX, Wang J, Shelburne CE, Lopatin DE, Chinnaiyan AM, Rubin MA, Pienta KJ and Taichman RS. Expression of CXCR4 and CXCL12 (SDF-1) in human prostate cancers (PCa) in vivo. J. Cell. Biochem. 2003; 89(3):462-473.

90. Jung SJ, Kim CI, Park CH, Chang HS, Kim BH, Choi MS and Jung HR. Correlation between Chemokine Receptor CXCR4 Expression and Prognostic Factors in Patients with Prostate Cancer. Korean J Urol. 2011; 52(9):607-611.

91. Dubrovska A, Elliott J, Salamone RJ, Telegeev GD, Stakhovsky AE, Schepotin IB, Yan F, Wang Y, Bouchez LC, Kularatne SA, Watson J, Trussell C, Reddy VA, Cho 
CY and Schultz PG. CXCR4 expression in prostate cancer progenitor cells. PloS one. 2012; 7(2):e31226.

92. Furusato B, Mohamed A, Uhlen M and Rhim JS. CXCR4 and cancer. Pathol. Int. 2010; 60(7):497-505.

93. Wendt MK, Cooper AN and Dwinell MB. Epigenetic silencing of CXCL12 increases the metastatic potential of mammary carcinoma cells. Oncogene. 2008; 27(10):14611471.

94. Liang Z, Wu T, Lou H, Yu X, Taichman RS, Lau SK, Nie S, Umbreit J and Shim H. Inhibition of breast cancer metastasis by selective synthetic polypeptide against CXCR4. Cancer Res. 2004; 64(12):4302-4308.

95. Li YM, Pan Y, Wei Y, Cheng X, Zhou BP, Tan M, Zhou X, Xia W, Hortobagyi GN, Yu D and Hung MC. Upregulation of CXCR4 is essential for HER2-mediated tumor metastasis. Cancer Cell. 2004; 6(5):459-469.

96. Phillips RJ, Burdick MD, Lutz M, Belperio JA, Keane MP and Strieter RM. The stromal derived factor-1/CXCL12CXC chemokine receptor 4 biological axis in non-small cell lung cancer metastases. Am. J. Respir. Crit. Care Med. 2003; 167(12):1676-1686.

97. Su L, Zhang J, Xu H, Wang Y, Chu Y, Liu R and Xiong $\mathrm{S}$. Differential expression of CXCR4 is associated with the metastatic potential of human non-small cell lung cancer cells. Clin. Cancer Res. 2005; 11(23):8273-8280.

98. Speetjens FM, Liefers GJ, Korbee CJ, Mesker WE, van de Velde CJ, van Vlierberghe RL, Morreau H, Tollenaar RA and Kuppen PJ. Nuclear localization of CXCR4 determines prognosis for colorectal cancer patients. Cancer Microenviron. 2009; 2(1):1-7.

99. Wendt MK, Johanesen PA, Kang-Decker N, Binion DG, Shah V and Dwinell MB. Silencing of epithelial CXCL12 expression by DNA hypermethylation promotes colonic carcinoma metastasis. Oncogene. 2006; 25(36):4986-4997.

100. Kim J, Mori T, Chen SL, Amersi FF, Martinez SR, Kuo C, Turner RR, Ye X, Bilchik AJ, Morton DL and Hoon DS. Chemokine receptor CXCR4 expression in patients with melanoma and colorectal cancer liver metastases and the association with disease outcome. Ann. Surg. 2006; 244(1):113-120.

101. Yasumoto K, Koizumi K, Kawashima A, Saitoh Y, Arita Y, Shinohara K, Minami T, Nakayama T, Sakurai H, Takahashi Y, Yoshie O and Saiki I. Role of the CXCL12/ CXCR4 axis in peritoneal carcinomatosis of gastric cancer. Cancer Res. 2006; 66(4):2181-2187.

102. Zhao BC, Wang ZJ, Mao WZ, Ma HC, Han JG, Zhao B and $\mathrm{Xu}$ HM. CXCR4/SDF-1 axis is involved in lymph node metastasis of gastric carcinoma. World J Gastroenterol. 2011; 17(19):2389-2396.

103. Ying J, Xu Q, Zhang G, Liu B and Zhu L. The expression of CXCL12 and CXCR4 in gastric cancer and their correlation to lymph node metastasis. Med Oncol. 2012; 29(3):17161722.

104. Kajiyama H, Shibata K, Terauchi M, Ino K, Nawa A and
Kikkawa F. Involvement of SDF-1alpha/CXCR4 axis in the enhanced peritoneal metastasis of epithelial ovarian carcinoma. Int. J. Cancer. 2008; 122(1):91-99.

105. Jiang YP, Wu XH, Shi B, Wu WX and Yin GR. Expression of chemokine CXCL12 and its receptor CXCR4 in human epithelial ovarian cancer: an independent prognostic factor for tumor progression. Gynecol. Oncol. 2006; 103(1):226233.

106. Akashi T, Koizumi K, Tsuneyama K, Saiki I, Takano Y and Fuse H. Chemokine receptor CXCR4 expression and prognosis in patients with metastatic prostate cancer. Cancer Sci. 2008; 99(3):539-542.

107. Marechal R, Demetter P, Nagy N, Berton A, Decaestecker C, Polus M, Closset J, Deviere J, Salmon I and Van Laethem JL. High expression of CXCR4 may predict poor survival in resected pancreatic adenocarcinoma. Br. J. Cancer. 2009; 100(9):1444-1451.

108. Marchesi F, Monti P, Leone BE, Zerbi A, Vecchi A, Piemonti L, Mantovani A and Allavena P. Increased survival, proliferation, and migration in metastatic human pancreatic tumor cells expressing functional CXCR4. Cancer Res. 2004; 64(22):8420-8427.

109. Franco R, Botti G, Mascolo M, Loquercio G, Liguori G, Ilardi G, Losito S, La Mura A, Calemma R, Ierano C, Bryce J, D'Alterio C and Scala S. "CXCR4-CXCL12 and VEGF correlate to uveal melanoma progression". Front Biosci (Elite Ed). 2010; 2:13-21.

110. Franco R, Cantile M, Scala S, Catalano E, Cerrone M, Scognamiglio G, Pinto A, Chiofalo MG, Caraco C, Anniciello AM, Abbruzzese A, Caraglia M and Botti G. Histomorphologic parameters and CXCR4 mRNA and protein expression in sentinel node melanoma metastasis are correlated to clinical outcome. Cancer Biol Ther. 2010; 9(6):423-429.

111. Scala S, Giuliano P, Ascierto PA, Ierano C, Franco R, Napolitano M, Ottaiano A, Lombardi ML, Luongo M, Simeone E, Castiglia D, Mauro F, De Michele I, Calemma R, Botti G, Caraco C, et al. Human melanoma metastases express functional CXCR4. Clin. Cancer Res. 2006; 12(8):2427-2433.

112. Kaifi JT, Yekebas EF, Schurr P, Obonyo D, Wachowiak R, Busch P, Heinecke A, Pantel K and Izbicki JR. Tumorcell homing to lymph nodes and bone marrow and CXCR4 expression in esophageal cancer. J. Natl. Cancer Inst. 2005; 97(24):1840-1847.

113. Koishi K, Yoshikawa R, Tsujimura T, Hashimoto-Tamaoki $\mathrm{T}$, Kojima S, Yanagi $\mathrm{H}$, Yamamura $\mathrm{T}$ and Fujiwara Y. Persistent CXCR4 expression after preoperative chemoradiotherapy predicts early recurrence and poor prognosis in esophageal cancer. World J Gastroenterol. 2006; 12(47):7585-7590.

114. Katayama A, Ogino T, Bandoh N, Nonaka S and Harabuchi Y. Expression of CXCR4 and its down-regulation by IFNgamma in head and neck squamous cell carcinoma. Clin. Cancer Res. 2005; 11(8):2937-2946. 
115. Eisenhardt A, Frey U, Tack M, Rosskopf D, Lummen G, Rubben $\mathrm{H}$ and Siffert W. Expression analysis and potential functional role of the CXCR4 chemokine receptor in bladder cancer. Eur. Urol. 2005; 47(1):111-117.

116. Oda Y, Yamamoto H, Tamiya S, Matsuda S, Tanaka K, Yokoyama R, Iwamoto Y and Tsuneyoshi M. CXCR4 and VEGF expression in the primary site and the metastatic site of human osteosarcoma: analysis within a group of patients, all of whom developed lung metastasis. Mod. Pathol. 2006; 19(5):738-745.

117. Russell HV, Hicks J, Okcu MF and Nuchtern JG. CXCR4 expression in neuroblastoma primary tumors is associated with clinical presentation of bone and bone marrow metastases. J. Pediatr. Surg. 2004; 39(10):1506-1511.

118. Savarin-Vuaillat C and Ransohoff RM. Chemokines and chemokine receptors in neurological disease: raise, retain, or reduce? Neurotherapeutics. 2007; 4(4):590-601.

119. Terasaki M, Sugita Y, Arakawa F, Okada Y, Ohshima K and Shigemori M. CXCL12/CXCR4 signaling in malignant brain tumors: a potential pharmacological therapeutic target. Brain Tumor Pathol. 2011; 28(2):89-97.

120. Wu S, Gessner R, Taube T, Korte A, von Stackelberg A, Kirchner R, Henze G and Seeger K. Chemokine IL-8 and chemokine receptor CXCR3 and CXCR4 gene expression in childhood acute lymphoblastic leukemia at first relapse. J. Pediatr. Hematol. Oncol. 2006; 28(4):216-220.

121. Guo L, Cui ZM, Zhang J and Huang Y. Chemokine axes CXCL12/CXCR4 and CXCL16/CXCR6 correlate with lymph node metastasis in epithelial ovarian carcinoma. Chin J Cancer. 2011; 30(5):336-343.

122. Villablanca EJ, Raccosta L, Zhou D, Fontana R, Maggioni D, Negro A, Sanvito F, Ponzoni M, Valentinis B, Bregni M, Prinetti A, Steffensen KR, Sonnino S, Gustafsson JA, Doglioni C, Bordignon C, et al. Tumor-mediated liver X receptor-alpha activation inhibits $\mathrm{CC}$ chemokine receptor-7 expression on dendritic cells and dampens antitumor responses. Nat. Med. 2010; 16(1):98-105.

123. Kim CH, Pelus LM, Appelbaum E, Johanson K, Anzai $\mathrm{N}$ and Broxmeyer HE. CCR7 ligands, SLC/6Ckine/ Exodus2/TCA4 and CKbeta-11/MIP-3beta/ELC, are chemoattractants for CD56(+)CD16(-) NK cells and late stage lymphoid progenitors. Cell. Immunol. 1999; 193(2):226-235.

124. Yoshida R, Nagira M, Imai T, Baba M, Takagi S, Tabira Y, Akagi J, Nomiyama $\mathrm{H}$ and Yoshie O. EBI1-ligand chemokine (ELC) attracts a broad spectrum of lymphocytes: activated T cells strongly up-regulate CCR7 and efficiently migrate toward ELC. Int. Immunol. 1998; 10(7):901-910.

125. Steinman RM, Pack M and Inaba K. Dendritic cells in the T-cell areas of lymphoid organs. Immunol. Rev. 1997; 156:25-37.

126. Gunn MD, Kyuwa S, Tam C, Kakiuchi T, Matsuzawa A, Williams LT and Nakano H. Mice lacking expression of secondary lymphoid organ chemokine have defects in lymphocyte homing and dendritic cell localization. J. Exp. Med. 1999; 189(3):451-460.

127. Mattern J, Koomagi R and Volm M. Association of vascular endothelial growth factor expression with intratumoral microvessel density and tumour cell proliferation in human epidermoid lung carcinoma. Br. J. Cancer. 1996; 73(7):931934.

128. Ding Y, Shimada Y, Maeda M, Kawabe A, Kaganoi J, Komoto I, Hashimoto Y, Miyake M, Hashida H and Imamura M. Association of CC chemokine receptor 7 with lymph node metastasis of esophageal squamous cell carcinoma. Clin. Cancer Res. 2003; 9(9):3406-3412.

129. Takeuchi H, Fujimoto A, Tanaka M, Yamano T, Hsueh $\mathrm{E}$ and Hoon DS. CCL21 chemokine regulates chemokine receptor CCR7 bearing malignant melanoma cells. Clin. Cancer Res. 2004; 10(7):2351-2358.

130. Takanami I. Overexpression of CCR7 mRNA in nonsmall cell lung cancer: correlation with lymph node metastasis. Int. J. Cancer. 2003; 105(2):186-189.

131. Muller A, Sonkoly E, Eulert C, Gerber PA, Kubitza R, Schirlau K, Franken-Kunkel P, Poremba C, Snyderman C, Klotz LO, Ruzicka T, Bier H, Zlotnik A, Whiteside TL, Homey B and Hoffmann TK. Chemokine receptors in head and neck cancer: association with metastatic spread and regulation during chemotherapy. Int. J. Cancer. 2006; 118(9):2147-2157.

132. Mashino K, Sadanaga N, Yamaguchi H, Tanaka F, Ohta M, Shibuta K, Inoue H and Mori M. Expression of chemokine receptor CCR7 is associated with lymph node metastasis of gastric carcinoma. Cancer Res. 2002; 62(10):2937-2941.

133. Gunther K, Leier J, Henning G, Dimmler A, Weissbach R, Hohenberger W and Forster R. Prediction of lymph node metastasis in colorectal carcinoma by expressionof chemokine receptor CCR7. Int. J. Cancer. 2005; 116(5):726-733.

134. Cunningham HD, Shannon LA, Calloway PA, Fassold BC, Dunwiddie I, Vielhauer G, Zhang M and Vines CM. Expression of the $\mathrm{C}-\mathrm{C}$ chemokine receptor 7 mediates metastasis of breast cancer to the lymph nodes in mice. Transl Oncol. 2010; 3(6):354-361.

135. Wiley HE, Gonzalez EB, Maki W, Wu MT and Hwang ST. Expression of $\mathrm{CC}$ chemokine receptor-7 and regional lymph node metastasis of B16 murine melanoma. J. Natl. Cancer Inst. 2001; 93(21):1638-1643.

136. Emmett MS, Lanati S, Dunn DB, Stone OA and Bates DO. CCR7 mediates directed growth of melanomas towards lymphatics. Microcirculation. 2011; 18(3):172-182.

137. Yang J, Wang S, Zhao G and Sun B. Effect of chemokine receptors CCR7 on disseminated behavior of human $\mathrm{T}$ cell lymphoma: clinical and experimental study. J. Exp. Clin. Cancer Res. 2011; 30:51.

138. Sperveslage J, Frank S, Heneweer C, Egberts J, Schniewind B, Buchholz M, Bergmann F, Giese N, Munding J, Hahn SA, Kalthoff H, Kloppel G and Sipos B. Lack of CCR7 
expression is rate limiting for lymphatic spread of pancreatic ductal adenocarcinoma. Int. J. Cancer. 2012; 131(4):E371-381.

139. Li P, Liu F, Sun L, Zhao Z, Ding X, Shang D, Xu Z and Sun C. Chemokine receptor 7 promotes cell migration and adhesion in metastatic squamous cell carcinoma of the head and neck by activating integrin alphavbeta3. Int. J. Mol. Med. 2011; 27(5):679-687.

140. Liu Y, Ji R, Li J, Gu Q, Zhao X, Sun T, Wang J, Du Q and Sun B. Correlation effect of EGFR and CXCR4 and CCR7 chemokine receptors in predicting breast cancer metastasis and prognosis. J. Exp. Clin. Cancer Res. 2010; 29:16.

141. Cabioglu N, Yazici MS, Arun B, Broglio KR, Hortobagyi GN, Price JE and Sahin A. CCR7 and CXCR4 as novel biomarkers predicting axillary lymph node metastasis in $\mathrm{T} 1$ breast cancer. Clin. Cancer Res. 2005; 11(16):5686-5693.

142. Arigami T, Natsugoe S, Uenosono Y, Yanagita S, Arima H, Hirata M, Ishigami S and Aikou T. CCR7 and CXCR4 expression predicts lymph node status including micrometastasis in gastric cancer. Int. J. Oncol. 2009; 35(1):19-24.

143. Kodama J, Hasengaowa, Kusumoto T, Seki N, Matsuo T, Ojima Y, Nakamura K, Hongo A and Hiramatsu Y. Association of CXCR4 and CCR7 chemokine receptor expression and lymph node metastasis in human cervical cancer. Ann. Oncol. 2007; 18(1):70-76.

144. Lopez-Giral S, Quintana NE, Cabrerizo M, Alfonso-Perez M, Sala-Valdes M, De Soria VG, Fernandez-Ranada JM, Fernandez-Ruiz E and Munoz C. Chemokine receptors that mediate B cell homing to secondary lymphoid tissues are highly expressed in B cell chronic lymphocytic leukemia and non-Hodgkin lymphomas with widespread nodular dissemination. J. Leukoc. Biol. 2004; 76(2):462-471.

145. Harris NL, Jaffe ES, Stein H, Banks PM, Chan JK, Cleary ML, Delsol G, De Wolf-Peeters C, Falini B, Gatter KC and et al. A revised European-American classification of lymphoid neoplasms: a proposal from the International Lymphoma Study Group. Blood. 1994; 84(5):1361-1392.

146. Weng AP, Ferrando AA, Lee W, Morris JPt, Silverman LB, Sanchez-Irizarry C, Blacklow SC, Look AT and Aster JC. Activating mutations of NOTCH1 in human T cell acute lymphoblastic leukemia. Science. 2004; 306(5694):269271.

147. Buonamici S, Trimarchi T, Ruocco MG, Reavie L, Cathelin S, Mar BG, Klinakis A, Lukyanov Y, Tseng JC, Sen F, Gehrie E, Li M, Newcomb E, Zavadil J, Meruelo D, Lipp M, et al. CCR7 signalling as an essential regulator of CNS infiltration in T-cell leukaemia. Nature. 2009; 459(7249):1000-1004.

148. Mburu YK, Egloff AM, Walker WH, Wang L, Seethala RR, van Waes $\mathrm{C}$ and Ferris RL. Chemokine receptor 7 (CCR7) gene expression is regulated by NF-kappaB and activator protein 1 (AP1) in metastatic squamous cell carcinoma of head and neck (SCCHN). J. Biol. Chem. 2012; 287(5):35813590 .
149. Liu FY, Zhao ZJ, Li P, Ding X, Guo N, Yang LL, Zong $\mathrm{ZH}$ and Sun CF. NF-kappaB participates in chemokine receptor 7-mediated cell survival in metastatic squamous cell carcinoma of the head and neck. Oncol. Rep. 2011; 25(2):383-391.

150. Wang J, Zhang X, Thomas SM, Grandis JR, Wells A, Chen ZG and Ferris RL. Chemokine receptor 7 activates phosphoinositide-3 kinase-mediated invasive and prosurvival pathways in head and neck cancer cells independent of EGFR. Oncogene. 2005; 24(38):5897-5904.

151. Mburu YK, Wang J, Wood MA, Walker WH and Ferris RL. CCR7 mediates inflammation-associated tumor progression. Immunol. Res. 2006; 36(1-3):61-72.

152. Zabel BA, Agace WW, Campbell JJ, Heath HM, Parent D, Roberts AI, Ebert EC, Kassam N, Qin S, Zovko M, LaRosa GJ, Yang LL, Soler D, Butcher EC, Ponath PD, Parker CM, et al. Human G protein-coupled receptor GPR9-6/CC chemokine receptor 9 is selectively expressed on intestinal homing $\mathrm{T}$ lymphocytes, mucosal lymphocytes, and thymocytes and is required for thymus-expressed chemokine-mediated chemotaxis. J. Exp. Med. 1999; 190(9):1241-1256.

153. Wurbel MA, Philippe JM, Nguyen C, Victorero G, Freeman T, Wooding P, Miazek A, Mattei MG, Malissen M, Jordan BR, Malissen B, Carrier A and Naquet P. The chemokine TECK is expressed by thymic and intestinal epithelial cells and attracts double- and single-positive thymocytes expressing the TECK receptor CCR9. Eur. J. Immunol. 2000; 30(1):262-271.

154. Bender GN, Maglinte DD, McLarney JH, Rex D and Kelvin FM. Malignant melanoma: patterns of metastasis to the small bowel, reliability of imaging studies, and clinical relevance. Am. J. Gastroenterol. 2001; 96(8):2392-2400.

155. Gill SS, Heuman DM and Mihas AA. Small intestinal neoplasms. J. Clin. Gastroenterol. 2001; 33(4):267-282.

156. Blecker D, Abraham S, Furth EE and Kochman ML. Melanoma in the gastrointestinal tract. Am. J. Gastroenterol. 1999; 94(12):3427-3433.

157. Letsch A, Keilholz U, Schadendorf D, Assfalg G, Asemissen AM, Thiel E and Scheibenbogen C. Functional CCR9 expression is associated with small intestinal metastasis. J. Invest. Dermatol. 2004; 122(3):685-690.

158. Amersi FF, Terando AM, Goto Y, Scolyer RA, Thompson JF, Tran AN, Faries MB, Morton DL and Hoon DS. Activation of CCR9/CCL25 in cutaneous melanoma mediates preferential metastasis to the small intestine. Clin. Cancer Res. 2008; 14(3):638-645.

159. Johnson-Holiday C, Singh R, Johnson E, Singh S, Stockard CR, Grizzle WE and Lillard JW, Jr. CCL25 mediates migration, invasion and matrix metalloproteinase expression by breast cancer cells in a CCR9-dependent fashion. Int. J. Oncol. 2011; 38(5):1279-1285.

160. Singh R, Stockard CR, Grizzle WE, Lillard JW, Jr. and Singh S. Expression and histopathological correlation of 
CCR9 and CCL25 in ovarian cancer. Int. J. Oncol. 2011; 39(2):373-381.

161. Homey B, Wang W, Soto H, Buchanan ME, Wiesenborn A, Catron D, Muller A, McClanahan TK, Dieu-Nosjean MC, Orozco R, Ruzicka T, Lehmann P, Oldham E and Zlotnik A. Cutting edge: the orphan chemokine receptor G protein-coupled receptor-2 (GPR-2, CCR10) binds the skin-associated chemokine CCL27 (CTACK/ALP/ILC). J. Immunol. 2000; 164(7):3465-3470.

162. Payne AS and Cornelius LA. The role of chemokines in melanoma tumor growth and metastasis. J. Invest. Dermatol. 2002; 118(6):915-922.

163. Simonetti O, Goteri G, Lucarini G, Filosa A, Pieramici T, Rubini C, Biagini G and Offidani A. Potential role of CCL27 and CCR10 expression in melanoma progression and immune escape. Eur. J. Cancer. 2006; 42(8):1181-1187.

164. Kai H, Kadono T, Kakinuma T, Tomita M, Ohmatsu H, Asano Y, Tada Y, Sugaya M and Sato S. CCR10 and CCL27 are overexpressed in cutaneous squamous cell carcinoma. Pathol. Res. Pract. 2011; 207(1):43-48.

165. Monteagudo C, Martin JM, Jorda E and Llombart-Bosch A. CXCR3 chemokine receptor immunoreactivity in primary cutaneous malignant melanoma: correlation with clinicopathological prognostic factors. J. Clin. Pathol. 2007; 60(6):596-599.

166. Kawada K, Sonoshita M, Sakashita H, Takabayashi A, Yamaoka Y, Manabe T, Inaba K, Minato N, Oshima M and Taketo MM. Pivotal role of CXCR3 in melanoma cell metastasis to lymph nodes. Cancer Res. 2004; 64(11):40104017.

167. Maekawa S, Iwasaki A, Shirakusa T, Kawakami T, Yanagisawa J, Tanaka T, Shibaguchi H, Kinugasa T and Kuroki M. Association between the expression of chemokine receptors CCR7 and CXCR3, and lymph node metastatic potential in lung adenocarcinoma. Oncol. Rep. 2008; 19(6):1461-1468.

168. Kawada K, Hosogi H, Sonoshita M, Sakashita H, Manabe T, Shimahara Y, Sakai Y, Takabayashi A, Oshima M and Taketo MM. Chemokine receptor CXCR3 promotes colon cancer metastasis to lymph nodes. Oncogene. 2007; 26(32):4679-4688.

169. Cambien B, Karimdjee BF, Richard-Fiardo P, Bziouech H, Barthel R, Millet MA, Martini V, Birnbaum D, Scoazec JY, Abello J, Al Saati T, Johnson MG, Sullivan TJ, Medina JC, Collins TL, Schmid-Alliana A, et al. Organ-specific inhibition of metastatic colon carcinoma by CXCR3 antagonism. Br. J. Cancer. 2009; 100(11):1755-1764.

170. Murakami T, Kawada K, Iwamoto M, Akagami M, Hida K, Nakanishi Y, Kanda K, Kawada M, Seno H, Taketo MM and Sakai Y. The role of CXCR3 and CXCR4 in colorectal cancer metastasis. Int. J. Cancer. 2013; 132(2):276-287.

171. Pradelli E, Karimdjee-Soilihi B, Michiels JF, Ricci JE, Millet MA, Vandenbos F, Sullivan TJ, Collins TL, Johnson MG, Medina JC, Kleinerman ES, Schmid-Alliana A and
Schmid-Antomarchi H. Antagonism of chemokine receptor CXCR3 inhibits osteosarcoma metastasis to lungs. Int. J. Cancer. 2009; 125(11):2586-2594.

172. Walser TC, Rifat S, Ma X, Kundu N, Ward C, Goloubeva O, Johnson MG, Medina JC, Collins TL and Fulton AM. Antagonism of CXCR3 inhibits lung metastasis in a murine model of metastatic breast cancer. Cancer Res. 2006; 66(15):7701-7707.

173. Ansel KM, Ngo VN, Hyman PL, Luther SA, Forster R, Sedgwick JD, Browning JL, Lipp M and Cyster JG. A chemokine-driven positive feedback loop organizes lymphoid follicles. Nature. 2000; 406(6793):309-314.

174. Okada T, Ngo VN, Ekland EH, Forster R, Lipp M, Littman DR and Cyster JG. Chemokine requirements for B cell entry to lymph nodes and Peyer's patches. J. Exp. Med. 2002; 196(1):65-75.

175. Airoldi I, Cocco C, Morandi F, Prigione I and Pistoia V. CXCR5 may be involved in the attraction of human metastatic neuroblastoma cells to the bone marrow. Cancer Immunol. Immunother. 2008; 57(4):541-548.

176. Chen G, Wang Z, Liu XY and Liu FY. High-level CXCR4 expression correlates with brain-specific metastasis of nonsmall cell lung cancer. World J. Surg. 2011; 35(1):56-61.

177. Paratore S, Banna GL, D'Arrigo M, Saita S, Iemmolo R, Lucenti L, Bellia D, Lipari H, Buscarino C, Cunsolo R and Cavallaro S. CXCR4 and CXCL12 immunoreactivities differentiate primary non-small-cell lung cancer with or without brain metastases. Cancer Biomark. 2011; 10(2):7989.

178. Lee BC, Lee TH, Avraham S and Avraham HK. Involvement of the chemokine receptor CXCR4 and its ligand stromal cell-derived factor 1alpha in breast cancer cell migration through human brain microvascular endothelial cells. Mol. Cancer Res. 2004; 2(6):327-338.

179. Andre F, Cabioglu N, Assi H, Sabourin JC, Delaloge S, Sahin A, Broglio K, Spano JP, Combadiere C, Bucana C, Soria JC and Cristofanilli M. Expression of chemokine receptors predicts the site of metastatic relapse in patients with axillary node positive primary breast cancer. Ann. Oncol. 2006; 17(6):945-951.

180. Izraely S, Klein A, Sagi-Assif O, Meshel T, Tsarfaty G, Hoon DS and Witz IP. Chemokine-chemokine receptor axes in melanoma brain metastasis. Immunol. Lett. 2010; 130(12):107-114. 